\title{
The Strategy of Disaster Mitigation Literacy through Problem-Based Learning (PBL) in the School Prone to Tidal Floods
}

\author{
Erni Suharini ${ }^{1}$, Dwi Putri Meliana ${ }^{2}$, Tjaturahono Budi Sanjoto ${ }^{3}$, Edi Kurniawan ${ }^{4}$ \\ \{erni.suharini@mail.unnes.ac.id ${ }^{1}$ \} \\ 1,2,3,4 Universitas Negeri Semarang, Indonesia
}

\begin{abstract}
A disaster becoming a great issue and it always happens nowadays. A school becomes an appropriate tool for spread knowledge of disaster widely that happens in environs. SMA N 10 Semarang is a school that located in the prone area of tidal floods. However, the lesson material of disaster and students' literacy capabilities still restricted. Hence, disaster mitigation literacy must be owned by students. The aim of this study is to present the strategy disaster mitigation literacy through PBL learning in the school prone to tidal floods. This research has been done in SMA Negeri 10 Semarang. The method that used was mixed method. The data collection used with observation, test, and interview. The technique of analyzing the data that used in this research is descriptive analysis. The results showed that the disaster mitigation literacy in the majority experiment class was at level 5 and was better than the control class with the majority being at level 3. In detail, the literacy improvement strategy for the students is; 1) giving disaster mitigation of literacy education through PBL learning; 2) increase the quality of science literacy though various readings; and 3) encourage improvement of awareness and skills of individual about disaster that concerns in the surrounding environment. The results of this study can be used as a reference in integrating disaster education in particular the mitigation of disasters in school learning so that the school formed disaster preparedness with a strong generation of disasters.
\end{abstract}

Keywords: Science Literacy, Disaster Mitigation, Disaster Prone Schools, Tidal Floods.

\section{Introduction}

School in the vulnerable areas of tidal floods are susceptible to flooding due to their location adjacent to the north coast of Java and have morphological conditions with alluvial plains with low slopes. Looking at the potential for disasters above, preparedness, early warning and disaster mitigation efforts are needed (Ervin et al., 2017). School is one of the main stakeholders in disaster education. School has enormous potential as a source of knowledge, dissemination of knowledge about disasters and practical guidance on what must be prepared before a disaster occurs and what must be done during and after disaster.

Today, disaster education, especially school disaster mitigation has been given in geography. This disaster education is carried out so that students will be able to adapt to disasters. Disaster mitigation education is used as a means to provide the information about the risks that can be caused by disasters. In addition, disaster mitigation education carried out 
is an effort to find out how much the level of knowledge about disaster mitigation (Putri et al., 2018).

The disruption of all kinds of school activities due to the occurrence of tidal floods certainly causes social change for schools that experience it. These social changes require schools in the tidal floods area to be able to adjust themselves to the situation. Tidal floods, which happened, required schools located in tidal floods vulnerable areas to have an attitude and strategy to do before and after a disaster. By given the fact that school vulnerable to floods, the schools should have begun to develop disaster mitigation strategies in accordance with their respective needs so that when the disaster arises from tidal floods' arrival. They are ready to anticipate so as minimize the impact of losses.

SMA N 10 Semarang is a school that located in the prone area of tidal floods. School is often exposed to flooding because of tides. Tidal floods happened based on Maritime $B M K G$ data from Semarang City for Genuk Sub-district in April 2019, there is a puddle of 10-50 cm high with intensity in the morning and evening (daily tidal floods type of the mixture leaning to double or mixes semidiurnal).

However, the lesson material of disaster and students' literacy capabilities still restricted. Hence, literacy of disaster mitigation is important to be owned by students.

Based on the explanation above, it should be integrated by disaster mitigation literacy in learning process. Literacy learning is the development of capabilities and activities based on the scientific knowledge that is relevant to daily life and career in making decision for problem-solving (Holbrook, 2009), the main purpose of using literacy strategies in learning are to build student understanding, writing skills and overall communication skills. These three things will lead to character development and high order thinking skills.

So far, there has been an opinion that literacy exists only in language learning or in language classes. This opinion is of course not appropriate because literacy develops in the fields of mathematics, science, social sciences, engineering, art, sports, health, economics, religion and crafts (Rob, 2003 in the Directorate General of Primary and Secondary Education of the Ministry of Education and Culture, 2017). One of the basic literacy agreed upon by the World Economic Forum in 2015 was scientific literacy. Disaster mitigation literacy is a part of science literacy because it functions the same, namely to form a mindset, behavior and build a human character to care and be responsible for himself/herself, society and the universe, as well as problems faced in society.

One of the cooperative learning models that is in accordance with the concept of scientific literacy is Problem Based Learning (PBL). Wachrodin (2017) Problem Based Learning (PBL) is a teaching approach that uses real-world problems as a context for students to think critically and problem-solving skills and to acquire essential knowledge and concepts from the subject matter. Whereas according to Siswono in (Nugroho \& Chotim, 2013) states that Problem Based Learning (PBL) is an approach to learning that begins by posing problems and proceeding to solve the problem.

Based on the explanation as a problem-solving effort, PBL can be used as a solution to find disaster mitigation strategies in schools in prone tidal floods area. Literacy of Strategy Disaster Mitigation above can be a reference for schools that have potential disasters to be included through learning. Literacy disaster mitigation is a step for preparing themselves to face of disaster risk.

The purpose of this study is to: (1) Know the literacy profile of students regarding disaster mitigation in class XI students at SMA N 10 Semarang. (2) Analyzing disaster mitigation literacy strategies through PBL learning in SMA N 10 Semarang. 


\section{Research Method}

This study is a mixed method with a sequential explanatory strategy type initiated by the use of quantitative methods followed by qualitative methods. The data collection techniques used in this study was observations, tests and interviews.

Quantitative data obtained through observations conducted during the learning process by observing, took into consideration then held a judgment with the highest score of 5 and the lowest score 1 catastrophic. Disaster mitigation test consists of four written questions about the process, concept, context and attitudes (PISA, 2017). The learners' answer to the four literacy questions assessed by researcher used rubric with a scale range $0-4$. Further qualitative data is obtained through in-depth interviews with teachers and students.

The population in this study was a grade XI student at SMA N 10 Semarang. The samples in quantitative research used purposive sampling with XI IPS Class 1 as the experimental class and XI IPS 3 as the control class. The subject of qualitative research taken with criteria can answer research issues including teachers and students. The validity test of data in the study was conducted through validity testing, and source triangulation techniques (Miles and Huberman, 2009). Analysis of research data using descriptive analysis (Sugiono, 2010).

\section{Results and Discussion}

\subsection{Level of Literacy of Student Disaster Mitigation}

Disaster mitigation literacy is the ability to deal with disaster threats through a set of knowledge covering all aspects needed as an effort to increase disaster risk reduction. The implementation of disaster mitigation literacy in schools is carried out in learning. Literacy activities in the learning phase are carried out to support the implementation of the 2013 curriculum which requires students to read non-textbook lessons using physical, social and effective environments, and academics accompanied by a variety of literacy (print, visual, auditory, digital) literature to enrich knowledge in subjects (GLS Guide in Senior High Schools, 2017). In this study, the questions are designed based on literacy instruments (OECD, 2017) which include content, process, context, and attitudes towards disaster mitigation. As for the level of scientific literacy, there are 6 indicators in Table 1. below as follows.

Table 1. Indicator of Assessment of the Level of Science Literacy

\begin{tabular}{ccl}
\hline Level & Score & \multicolumn{1}{c}{ Description } \\
\hline 6 & 708 & $\begin{array}{l}\text { Students can explain with arguments to criticize and evaluate problems in } \\
\text { various personal, local and global contexts. }\end{array}$ \\
\hline 5 & 633 & $\begin{array}{l}\text { Students can demonstrate the ability to make appropriate judgments about } \\
\text { complex circumstances. Students are able to show evidence of scientific } \\
\text { thinking with the reasoning that requires the use of models. Some of them } \\
\text { can criticize and evaluate explanations, models, interpretations of data but } \\
\text { not in all local and global contexts. }\end{array}$ \\
\hline 4 & 559 & $\begin{array}{l}\text { Students can distinguish questions scientifically / non-scientifically. } \\
\text { Students can change and interpret data and have scientific opinions. Level }\end{array}$ \\
\hline
\end{tabular}




\begin{tabular}{ccl}
\hline r & & $\begin{array}{l}4 \text { students show scientific thinking accompanied by reasons and applied } \\
\text { in certain situations. }\end{array}$ \\
\hline 3 & 484 & $\begin{array}{l}\text { Students are able to think and show some scientific evidence related to } \\
\text { the context of everyday life. Students can develop arguments and analyze } \\
\text { critically in local and global contexts. }\end{array}$ \\
\hline 2 & 410 & $\begin{array}{l}\text { Students can use knowledge to explain, evaluate and design scientific } \\
\text { questions and interpret data in several life situations. }\end{array}$ \\
\hline 1 & 335 & $\begin{array}{l}\text { Students can use their knowledge to provide scientific explanations in the } \\
\text { context of daily life situations but cognitive aspects are still low. }\end{array}$ \\
\hline
\end{tabular}
Source: PISA (2017).

The level of disaster mitigation literacy refers to PISA (2017) which is divided into 6 levels. This level shows the differences in disaster mitigation literacy abilities of each student which can be seen in the following Table 2 .

Table 2. Level of Literacy for Student Disaster Mitigation

\begin{tabular}{ccccc}
\hline Level & $\begin{array}{c}\text { Control } \\
\text { Class }\end{array}$ & $\begin{array}{c}\text { Percentage } \\
(\mathbf{\%})\end{array}$ & $\begin{array}{c}\text { Experiment } \\
\text { Class }\end{array}$ & $\begin{array}{c}\text { Percentage } \\
(\boldsymbol{\%})\end{array}$ \\
\hline $\mathbf{6}$ & 0 & 0 & 4 & 11.1 \\
\hline $\mathbf{5}$ & 3 & 8.33 & 17 & 47.2 \\
\hline $\mathbf{4}$ & 12 & 33.3 & 15 & 41.6 \\
\hline $\mathbf{3}$ & 15 & 41.6 & 0 & 0 \\
\hline $\mathbf{2}$ & 5 & 13.8 & 0 & 0 \\
\hline $\mathbf{1}$ & 1 & 2.7 & 0 & 0 \\
\hline
\end{tabular}

Source : Primary Data, processed (2019).

Based on the results of the disaster mitigation literacy index analysis, the aggregate level of mitigation literacy of students at SMAN 10 Semarang in the control class is mostly at level 3 with a percentage of 41.6. This condition is different in the experimental class who learned about disaster mitigation material through PBL with a more significant increase with the majority of 47.2 being at level 5 . The aggregate differences in learners' disaster mitigation literacy from the control class and experimentation were due to the learning process using PBL running well.

PBL learning process consists of 5 phases, namely: (1) problem orientation; (2) organizing work groups; (3) independent and group investigations; (4) discussion and developing work; (5) evaluation of problem-solving (Hosnan, 2016). Based on the observation sheet the implementation of PBL learning scores from the average observer 4.3 from a maximum score of 5 this indicates that the learning process using PBL has gone very well so the level of student disaster mitigation literacy in the experimental class is better than the control class.

Judging from the level of disaster mitigation literacy, students are still at level 1 before being treated with a number of 12 students, while after being given treatment, it increases to level 5 with 17 students. Increasing the level of students' mitigation literacy because of the application of the four components to literacy according to the OECD (2017) which consists of 4 components namely process components, content components, context components, and attitude components. The application of these four literacy components requires specific and basic competencies with form and degree diverse. 
Students with the ability to be level 5 can be interpreted that students have been able to connect their knowledge of disaster with the occurrence of tidal floods that occur in the surrounding environment. Students can also analyze problems and provide alternative solutions. With this skill, students can connect the knowledge of disaster, technology and society as a comprehensive unity and needed by each student in preparing the disaster risk that occurs in the environment. Students with high disaster mitigation literacy are required as stakes holder in the dissemination of disaster education.

\subsection{Literacy Strategy for Disaster Mitigation through PBL Learning}

To build a culture of literacy in the entire educational realm (family, school, and society), since 2016 the Ministry of Education and Culture has intensified the National Literacy Movement (GLS) as part of the implementation of Minister of Education and Culture Regulation No. 23 in 2015 concerning the Growth of Character (Effendy, 2017 in the Directorate General of Primary and Secondary Education of the Ministry of Education and Culture, 2017). Specifically, improving disaster mitigation literacy can be done through several priority strategies, especially for students, namely 1) providing disaster mitigation literacy education through PBL learning; 2) improve the quality of scientific literacy through various readings (print, visual, auditory, digital); and 3) encourage increased awareness and individual skills about concern for disasters in the surrounding environment.

First, efforts to improve disaster mitigation literacy through PBL Learning can be applied in Geographical subjects through several things such as concentrating students on tidal floods problem which often occurs in the environment around schools, organizes students with exercises related to disaster problems that often occur in Indonesia in generally, encouraging students to gather information that is appropriate for resolving disaster problems that occur, the results of problem-solving are made in the form of reports, videos, models, then students do reflection or evaluation of the process of solving these hate problems, this can improve student disaster mitigation literacy.

Second, efforts to improve the quality of scientific literacy through various readings, the provision of instruments and the development of teaching materials, among others, by increasing learners' access to all information regarding good mitigation in print, visual, auditory, digital. So the government through the Ministry of Education must provide supporting infrastructure for schools in disaster-prone areas. This aims to encourage deepening and expansion of access to minimize the risk of disasters that occur.

Third, encourage awareness and individual skills about disaster awareness in the surrounding environment. Skills that must be possessed by students to improve their ability to solve problems that occur when they are in disaster-prone areas. Awareness and concern in maintaining the environment is a form of someone who has been literate towards disaster.

\section{Conclusion}

Student disaster Mitigation Literacy XI IPS 1 class as an experimental class is better than the XI IPS Class 3 as the control class. Based on the results of the post test class XI IPS 1 The majority is at level 5 while XI IPS Class 3 majority are in Level 3 this is influenced because the process of learning the PBL runs very well. 
Specifically, increasing disaster mitigation literacy can be done through several priority strategies, especially for students, namely1) providing disaster mitigation literacy education through PBL learning; 2) improve the quality of scientific literacy through various readings (print, visual, auditory, digital); and 3) encourage increased awareness and individual skills about concern for disasters in the surrounding environment.

The results of this research can be used as a reference in integrating disaster education especially the mitigation of disasters in school learning so that the school formed disaster preparedness with a strong generation of disasters. Students that have sufficient potential to improve disaster mitigation literacy indicated by the desire to obtain all information related to disasters that occur in Indonesia in general and the surrounding environment located in disaster-prone to tidal floods areas in particular.

The potential of students to be well literate must be supported by relevant stakeholders both stakeholders, such as literacy activists, academics, professional organizations, the business world, and other ministries/institutions to improve socialization regarding the role and benefits of disaster mitigation for Indonesian people with high potential for disaster.

\section{References}

Creswell, J.W. 2013. Research Design: Pendekatan Kualitatif, Kuantitatif, dan Mixed. Terjemahan Achmad Fawaid. Yogyakarta: Pustaka Belajar.

Ditjen Dikdasmen Kementerian Pendidikan dan Kebudayaan (2017). Strategi Literasi Dalam Pembelajaran Di Sekolah Menengah Atas.

Ervin, Akhmad, Santoso, A.B, Juhadi. 2017. Pelaksanaan Program Siaga Bencana Di Sekolah Menengah Pertama Pada Kawasan Rawan Bencana. Jurnal Geografi, 5 (3) ISSN 22526684.

Holbrook, J., Rannikmae, M. 2009. The Meaning of Scientific Literacy. International Journal of Environmental and Science Education, 4(3): 275-288

Hosnan, M. 2016. Pendidikan Saintifik dan Kontekstual dalam Pembelajaran Abad 21. Bogor: Penerbit Ghalia Indonesia.

Miles, M. B., \& Huberman, A. M. (2009). Qualitative data analysis: An expanded sourcebook. Thousand Oaks, CA: Sage.

Nugroho, I. A., Chotim, M., \& Dwijanto, D. (2013). Keefektifan Pendekatan Problem Based Learning Terhadap Kemampuan Berpikir Kreatif Matematik. Unnes Journal of Mathematics Education, 2(1).

OECD (2017), PISA for Development Assessment and Analytical Framework: Reading, Mathematics and Science, Preliminary Version. OECD Publishing, Paris.

Putri, N.A.E, Sanjoto, T.B, Sriyanto. 2018. Pendidikan Mitigasi Bencana Tsunami dengan Menggunakan Media Pembelajaran Buku Saku Pada Masyarakat Pesisir Desa Karanggadung Kecamatan Petanahan Kabupaten Kebumen. Jurnal Geografi, 6(1) ISSN $2252-6684$.

Sugiyono. 2013. Metode Penelitian Kuantitatif, Kualitatif dan $R \& D$. Bandung: Alfabeta.

Wachrodin. 2017. Peningkatan Kemampuan Pemecahan Masalah dan Keaktifan Siswa Melalui Model Problem Based Learning (PBL) dengan Penugasan Berstruktur. Jurnal Penelitian Pendidikan. 34 (1). 